\title{
Degradation of Monocyte Chemoattractant Protein-1 by Tryptase Co-Released in Immunoglobulin E-Dependent Activation of Primary Human Cultured Mast Cells
}

\author{
Issan Yee San Tam ${ }^{\mathrm{a}}$ Chun Wai Ng ${ }^{\mathrm{a}}$ Hang Yung Alaster Lau ${ }^{\mathrm{a}}$ See-Ying Tam ${ }^{\mathrm{b}, \mathrm{c}}$ \\ a School of Biomedical Sciences, Faculty of Medicine, Chinese University of Hong Kong, Shatin, China; \\ ${ }^{b}$ Department of Pathology, Stanford University School of Medicine, Stanford, CA, USA; \\ 'Sean N. Parker Center for Allergy and Asthma Research, Stanford University School of Medicine, Stanford, CA, USA
}

\section{Keywords}

Human mast cells · Immunoglobulin E · Mast cell tryptase · Monocyte chemoattractant protein- $1 \cdot$ Mediator release

\begin{abstract}
Background: Mast cells are key immune effector cells which release chemokines, proteases, and other inflammatory mediators upon activation by immunological stimuli. The aim of this study was to investigate the effects of co-releasing proteases on the kinetics of release of the chemokine monocyte chemoattractant protein-1 (MCP-1) in immunoglobulin E ( $(\mathrm{gE}$ )-mediated activation of human mast cells. Methods: Homogenous populations of mature and functional primary human mast cells were generated from $\mathrm{CD} 34^{+}$progenitors originated from buffy coats of healthy adult donors. The releases of MCP-1 from human mast cells in basal conditions
\end{abstract}

This work was conducted at the School of Biomedical Sciences, Faculty of Medicine, Chinese University of Hong Kong.

Edited by: H.-U. Simon, Bern.

\section{KARGER}

() 2018 S. Karger AG, Basel

E-Mail karger@karger.com

www.karger.com/iaa and in response to FcعRl cross-linking were assessed at different time points. The effects of different types of protease inhibitors on MCP-1 release from these mast cells under stimulated or unstimulated conditions were also investigated. Results: Cultured human mast cells released MCP-1 in basal conditions and its levels increased in a time-dependent manner. When stimulated by FcERI cross-linking, the levels of MCP-1 detected in the medium gradually decreased over time after the initial peak induction. Such a decline in MCP-1 levels after IgE-dependent activation was completely prevented by pretreatment with a cocktail of protease inhibitors or the specific tryptase inhibitor APC366. Conclusions: Direct regulation of MCP-1 expression by co-release of tryptase in cultured human mast cells upon IgE-dependent activation demonstrates a role of the serglycin:serine protease axis in modulation of inflammatory reactions through proteolytic degradation of mediators such as chemokines.

(c) 2018 S. Karger AG, Base

Prof. Hang Yung Alaster Lau

School of Biomedical Sciences

Chinese University of Hong Kong

506A, Lo Kwee-Seong, Shatin, Hong Kong (China)

E-Mail hyalau@cuhk.edu.hk

Dr. See-Ying Tam

Department of Pathology

Stanford University School of Medicine

269 Campus Drive, Stanford, CA 94305 (USA)

E-Mail stam@stanford.edu 


\section{Introduction}

Mast cells are key immune effector cells that mediate immunoglobulin E (IgE)-dependent immediate hypersensitivity reactions. Cross-linking of high-affinity $\operatorname{IgE}$ receptors (FceRI) expressed on mast cells by allergen-specific IgE and allergens leads to degranulation with the immediate release of preformed mediators such as histamine, which is followed by de novo synthesis and release of lipid mediators and cytokines [1,2]. Proteases, like histamine, are preformed and stored in secretory granules of mast cells until they are released through degranulation induced by IgE-dependent or IgE-independent mast cell activation. Through proteolytic modification of immunoreactive cytokines/chemokines in the immediate microenvironment in which mast cell degranulation occurs, the released proteases have been suggested to contribute significantly to the pathophysiological functions of mast cells in inflammation, wound healing, and innate immunity. Several recent studies using different mouse models have provided further evidence that serglycin proteoglycan and its associated proteases present in the granules of mast cells are involved in regulation of many inflammatory responses through either proteolytic activation or proteolytic degradation of cytokines that are present in the extracellular space [3-5].

We recently reported a novel protocol that can generate high yields of mature human connective tissue type $\left(\mathrm{MC}_{\mathrm{TC}}\right)$ mast cells after only 6 weeks of culture [6]. In our studies on the release of cytokines and chemokines from human mast cells generated by our protocol, we observed that these cells spontaneously released the chemokine monocyte chemoattractant protein (MCP)-1 in basal conditions and that its release increased in a time-dependent manner. Interestingly, upon FceRI-dependent activation, the levels of MCP-1 released from these human mast cells were found to gradually decrease over time after the initial peak induction. It has previously been shown in studies with purified human skin-derived mast cells that granular proteases, such as chymase and cathep$\sin \mathrm{G}$, released upon FceRI cross-linking can degrade cytokines that are co-released from these activated mast cells [7]. Since MCP-1 is an important chemokine that regulates the migration and infiltration of leucocytes from the circulation to sites of inflammation [8], we were interested to investigate whether the reduction in MCP-1 levels observed after human mast cell activation was due to the proteolytic action of the proteases released by degranulation, which thereby limits the leucocyte-attracting property of tissue mast cells. In this study, we report that the decline in MCP-1 levels detected in the medium after IgE-dependent cell activation was completely prevented by pretreatment with protease inhibitor cocktail or specific tryptase inhibitor APC366, suggesting the direct regulation of MCP-1 protein levels by tryptase coreleased by primary human cultured mast cells (HCMC) upon IgE-dependent activation.

\section{Materials and Methods}

\section{Materials}

Iscove's modified Dulbecco's medium (IMDM), insulin-transferrin-selenium, 2-mercaptoethanol, penicillin-streptomycin, fetal bovine serum, stem cell factor (SCF), IL-3, and IL-6 were purchased from Invitrogen. IL-4 and IL-9 were purchased from PeproTech. Human myeloma immunoglobulin (IgE) was purchased from Calbiochem. Bestatin, chymostatin, substance $\mathrm{P}$, and antihuman IgE (AE) were purchased from Sigma-Aldrich, and $1 \times$ protease inhibitor cocktail tablets were purchased from Roche. APC366 was purchased from Tocris Bioscience.

\section{Generation of HCMC}

Primary human mast cells with characteristics of the connective tissue type $\left(\mathrm{MC}_{\mathrm{TC}}\right)$ phenotype were generated using a protocol previously described by our group [6]. Briefly, CD $34^{+}$progenitors isolated from fresh adult peripheral blood buffy coat using the MACS system (Miltenyi Biotec) were cultured in complete IMDM (with $1 \times$ insulin-transferrin-selenium, $1 \times$ penicillin-streptomycin, $50 \mu \mathrm{M} 2$-mercaptoethanol, and $0.1 \%$ BSA) with $200 \mathrm{ng} / \mathrm{mL}$ SCF, $100 \mathrm{ng} / \mathrm{mL}$ IL-6, and $1 \mathrm{ng} / \mathrm{ml}$ IL-3 for 1 week. Subsequently, the spent medium was replaced by complete IMDM with $200 \mathrm{ng} /$ mL SCF, 100 ng/mL IL-6, and 15 ng/mL IL-9 for another week. For these initial 2 weeks of culturing, cells were incubated in hypoxic conditions $\left(5 \% \mathrm{CO}_{2}, 5 \% \mathrm{O}_{2}\right.$, and $\left.37^{\circ} \mathrm{C}\right)$. After the first 2 weeks, the spent medium was replaced by complete IMDM with $200 \mathrm{ng} / \mathrm{mL}$ SCF and 100 ng/mL IL-6 weekly for another 2 weeks. At week 5, the spent medium was replaced by complete IMDM with $200 \mathrm{ng} /$ $\mathrm{mL}$ SCF, $100 \mathrm{ng} / \mathrm{mL}$ IL-6, and $10 \mathrm{ng} / \mathrm{mL}$ IL-4. From week 6 and thereafter, cells were cultured in complete IMDM with $100 \mathrm{ng} / \mathrm{mL}$ SCF and $50 \mathrm{ng} / \mathrm{mL}$ IL-6. From week 3 onwards, these cultures were incubated in normoxic conditions $\left(5 \% \mathrm{CO}_{2}, 21 \% \mathrm{O}_{2}\right.$, and $\left.37^{\circ} \mathrm{C}\right)$. After week 6, fully mature and homogenous populations of HCMC were generated and ready for functional studies.

\section{Measurement of Histamine Release}

The release of histamine from mature cultured human mast cells (cultured for $\geq 6$ weeks) was measured as previously described [6]. Briefly, the cells were harvested, counted, seeded, and sensitized with $0.5 \mu \mathrm{g} / \mathrm{mL}$ human myeloma IgE overnight in complete IMDM with $100 \mathrm{ng} / \mathrm{mL}$ SCF and $50 \mathrm{ng} / \mathrm{mL}$ IL-6. The cells were then washed once in PBS and resuspended in full HEPES buffer (137 mM NaCl, $5.56 \mathrm{mM}$ glucose, $12 \mathrm{mM}$ HEPES, $2.7 \mathrm{mM}$ $\mathrm{KCl}, 0.4 \mathrm{mM} \mathrm{NaH}_{2} \mathrm{PO}_{4}, 1 \mathrm{mM} \mathrm{MgCl}$, and $1 \mathrm{mM} \mathrm{CaCl}_{2}$ at $\mathrm{pH} 7.4$ ) with $0.03 \% \mathrm{HSA}$ and then challenged by anti-IgE or substance $\mathrm{P}$ for $30 \mathrm{~min}$ at $37^{\circ} \mathrm{C}$. The reaction was stopped by the addition of ice-cold buffer and chilling on ice. Samples of cell-free supernatant and corresponding cell pellets were then collected by cen- 
trifugation at $4{ }^{\circ} \mathrm{C}$. Cells incubated in buffer alone served as the controls for spontaneous histamine release. The histamine contents in mast cell pellets and supernatants were measured spectrofluorometrically using the Bran+Luebbe AutoAnalyzer 3. Histamine release was expressed as a percentage of the total cellular contents of histamine (the sum of the supernatant content and the cell pellet content) that were released into the supernatant (histamine release, \%).

\section{Measurements of Releases of MCP-1 and IL-8}

IgE-sensitized or naive mature cultured human mast cells were washed and resuspended in complete IMDM containing $100 \mathrm{ng} /$ $\mathrm{mL}$ SCF, $50 \mathrm{ng} / \mathrm{mL}$ IL-6, and $10 \%$ fetal bovine serum. The cells were stimulated with $0.25 \mu \mathrm{g} / \mathrm{mL}$ anti-IgE at $37^{\circ} \mathrm{C}$ overnight and the culture medium was then harvested with cells removed by centrifugation at $4{ }^{\circ} \mathrm{C}$. For time course experiments, media were harvested at selected time points after activation with anti-IgE and frozen at $-80^{\circ} \mathrm{C}$. The amounts of MCP- 1 and IL- 8 released into the culture medium were measured using ELISA (BD) and presented as $\mathrm{ng} / 10^{6}$ cells.

\section{Protease Inhibitor Studies}

For studies employing protease inhibitors, IgE-sensitized cultured human mast cells were stimulated with $0.25 \mu \mathrm{g} / \mathrm{mL}$ anti- $\mathrm{IgE}$ at $37^{\circ} \mathrm{C}$ for $6 \mathrm{~h}$. The culture media were then harvested and treated with different protease inhibitors or water under the following experimental conditions:

1. Frozen 6-h reaction: samples were harvested at the 6th hour and immediately frozen at $-80^{\circ} \mathrm{C}$.

2. Water control: samples were harvested at the 6th hour and treated with water and kept at $37^{\circ} \mathrm{C}$ for another $16 \mathrm{~h}$.

3. Protease inhibitor cocktail: samples were harvested at the 6th hour and treated with $1 \times$ Roche protease inhibitor cocktail at $37^{\circ} \mathrm{C}$ for another $16 \mathrm{~h}$.

4. APC366 (specific inhibitor of mast cell tryptase): samples were harvested at the 6 th hour and treated with $500 \mu \mathrm{g} / \mathrm{mL}$ APC366 at $37^{\circ} \mathrm{C}$ for another $16 \mathrm{~h}$.

5. Bestatin (specific inhibitor of metalloprotease): samples were harvested at the 6 th hour and treated with $500 \mu \mathrm{M}$ bestatin at $37^{\circ} \mathrm{C}$ for another $16 \mathrm{~h}$.

6. Chymostatin (specific inhibitor of chymotrypsin): samples were harvested at the 6 th hour and treated with $100 \mu \mathrm{g} / \mathrm{mL}$ chymostatin at $37^{\circ} \mathrm{C}$ for another $16 \mathrm{~h}$.

7. Frozen $16-\mathrm{h}$ reaction: samples were harvested at the 16 th hour and immediately frozen at $-80^{\circ} \mathrm{C}$.

\section{Quantitative PCR}

The primer sequences were as follows:

MCP-1: forward 5'-CGCTCAGCCAGATGCAATCAA-3'; re-

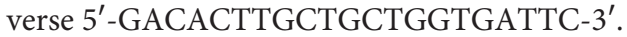

GAPDH: forward 5'-AGGTGAAGGTCGGAGTC-3'; reverse 5'-GGAAGATGGTGATGGGATT3'.

Real-time qPCR was performed using SYBR Premix Ex Taq (Tli RNaseH Plus) (Takara) with the 7900HT Fast Real-Time PCR System (ABI). Cycle thresholds (Ct) for MCP-1 and GAPDH transcripts were determined. Relative fold changes between the expression of the genes of interest in treated and untreated samples were determined via the $2^{-(\mathrm{ddCt})}$ method. Each treatment sample was assessed using 3 different batches of primary mast cell cultures. All of the samples were repeated in triplicate.

Degradation of MCP-1 by Human Mast

Cell Tryptase
Statistical Analysis

Statistical analysis was performed using GraphPad Prism 5 (version 5.02). The levels of release of MCP-1 and IL- 8 determined by ELISA are presented as means \pm SEM (in ng/ $10^{6}$ cells). Statistical significance was determined using a paired $t$ test, an unpaired $t$ test or a one-way ANOVA where appropriate.

\section{Results}

\section{Spontaneous Release of MCP-1 from HCMC and Its}

Reduction by Anti-IgE Stimulation

Anti-IgE stimulation induced degranulation in our HCMC, resulting in the immediate release of histamine (Fig. 1a; unstimulated spontaneous release: $4.0 \pm 1.1 \%$; anti-IgE stimulated release: $39.0 \pm 2.0 \%$ ). Release of MCP1 from IgE-sensitized HCMC was also readily detected $16 \mathrm{~h}$ after anti-IgE stimulation (Fig. $1 \mathrm{~b} ; 8.6 \pm 1.2 \mathrm{ng} / 10^{6}$ cells). Interestingly, significantly higher levels of MCP-1 were spontaneously released from these IgE-sensitized HCMC that had not been stimulated by anti-IgE (Fig. 1b; $58.0 \pm 3.3 \mathrm{ng} / 10^{6}$ cells). Indeed, similar levels of MCP-1 were released by naive non-IgE sensitized HCMC in the absence or presence of anti-IgE (Fig. 1b; $57.9 \pm 1.9$ and $53.4 \pm 3.4 \mathrm{ng} / 10^{6}$ cells, respectively). These data suggest that MCP-1 was spontaneously released from HCMC into the medium, while FceRI activation induced a significant decrease in the levels of MCP-1 detected in the medium. On the other hand, IL-8 release from HCMC was only detected after FceRI cross-linking (Fig. 1b; unstimulated: $0.2 \pm 0.1 \mathrm{ng} / 10^{6}$ cells; anti-IgE stimulation: $57.9 \pm 11.5 \mathrm{ng} / 10^{6}$ cells), and the released levels were similar to those observed in our previous study [6], thus implying that these HCMC responded to IgE-dependent cell activation in the typical expected manner.

Nonimmunological activation by substance $P$ resulted in degranulation which was represented by a significant histamine release (Fig. 1c; spontaneous release: $3.4 \pm$ $0.3 \%, 1 \mu \mathrm{M}$ substance P: $71.5 \pm 5.3 \%, 10 \mu \mathrm{M}$ substance P: $71.5 \pm 2.5 \%)$. Similar to anti-IgE induced activation, the levels of spontaneously released MCP-1 were significantly reduced following activation induced by substance $\mathrm{P}$ (Fig. 1d; unstimulated: $70.6 \pm 3.1 \mathrm{ng} / 10^{6}$ cells; $1 \mu \mathrm{M}$ substance P: $12.9 \pm 1.7 \mathrm{ng} / 10^{6}$ cells; $10 \mu \mathrm{M}$ substance P: $7.2 \pm$ $0.8 \mathrm{ng} / 10^{6}$ cells; $n=3$ ).

\section{Time Course of Release of MCP-1 from HCMC under Basal Conditions and in Response to Anti-IgE Stimulation}

To elucidate the mechanisms underlying the decrease in MCP-1 release induced by anti-IgE stimulation ob- 
Fig. 1. Release of histamine and cytokines from human cultured mast cells in basal condition and in response to activation by anti-IgE or substance P. a Release of histamine in basal conditions and in response to $0.25 \mu \mathrm{g} / \mathrm{mL}$ anti-IgE $(n=5)$. b Release of MCP-1 and IL-8 in basal conditions and in response to $0.25 \mu \mathrm{g} / \mathrm{mL}$ anti-IgE stimulation $(n=4)$. c Release of histamine in basal conditions and in response to substance $\mathrm{P}$ (SP) stimulation $(n=3)$. d Release of MCP1 in response to stimulation by substance $\mathrm{P}$ $(n=3)$. All values are means \pm SEM. ${ }^{*} p<$ $0.05,{ }^{* *} p<0.01$, and ${ }^{* * *} p<0.001$ by paired $t$ test when compared with corresponding basal values obtained with unstimulated cells.
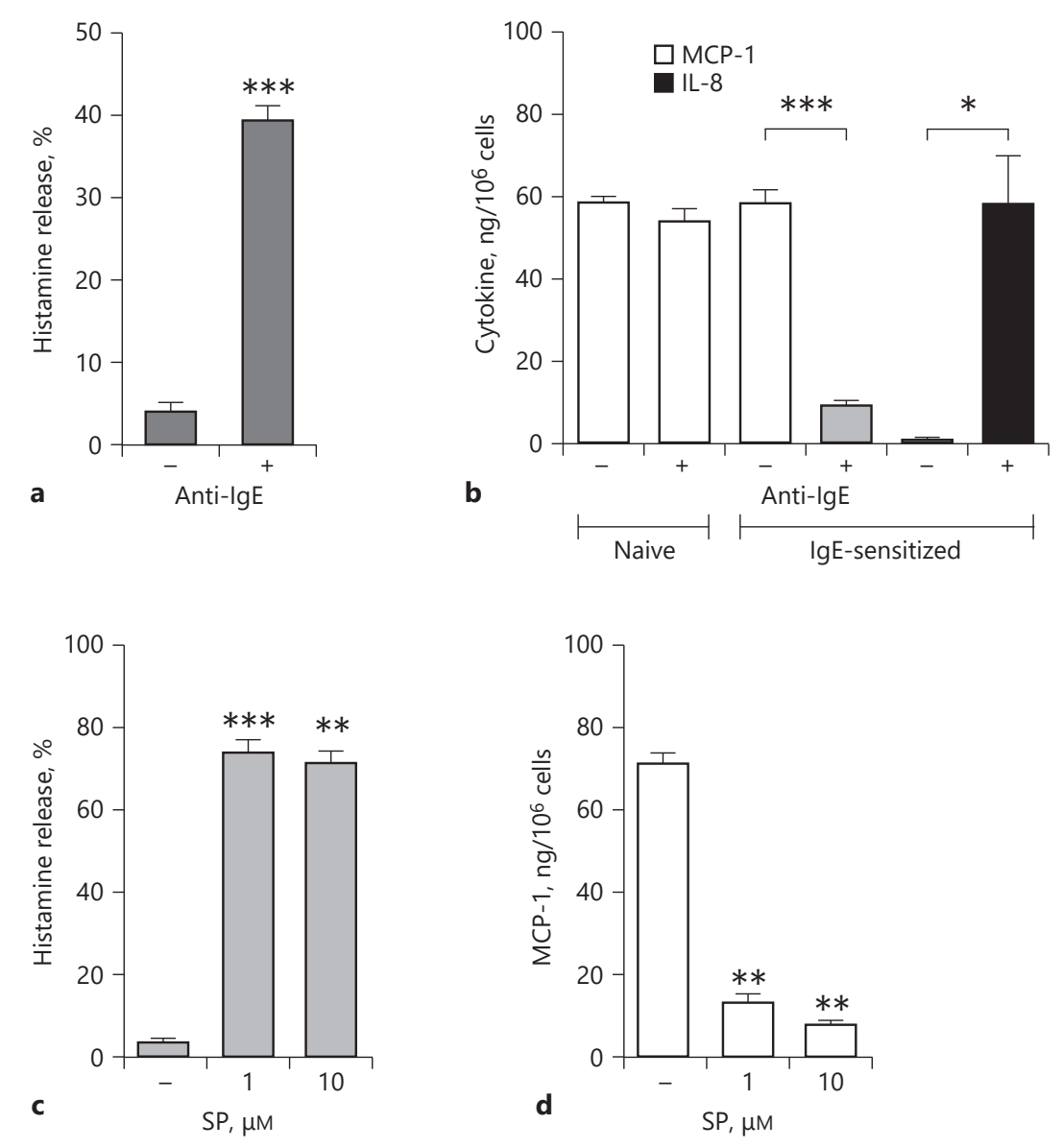

served with HCMC, MCP-1 release was assessed 1, 2, 3, $6,9,16$, and $24 \mathrm{~h}$ after activation. As shown in Figure 2a, MCP-1 protein was spontaneously released from HCMC and steadily accumulated in the culture medium in a time-dependent manner from the 1st to the 24th hour. In contrast, as illustrated in Figure 2b, anti-IgE activated HCMC released higher levels of MCP-1 compared to those in the basal state at the 1 st hour $(5.8 \pm 1.5$ vs. $2.3 \pm$ $0.6 \mathrm{ng} / 10^{6}$ cells), and the induced levels of MCP-1 became increasingly higher at the 2nd hour $(16.3 \pm 5.0$ $\mathrm{ng} / 10^{6}$ cells $)$ and $3 \mathrm{rd}$ hour $\left(27.3 \pm 7.3 \mathrm{ng} / 10^{6}\right.$ cells $)$ and peaked at the 6th hour $\left(29.8 \pm 10.9 \mathrm{ng} / 10^{6}\right.$ cells) (Fig. 2a). However, the levels of MCP-1 started to decrease from the 9 th hour $\left(24.8 \pm 7.7 \mathrm{ng} / 10^{6}\right.$ cells $)$ and were lower than those of the corresponding spontaneous release levels (Fig. $2 \mathrm{a})$ at the 16 th hour $\left(9.1 \pm 5.8\right.$ vs. $23.3 \pm 5.4 \mathrm{ng} / 10^{6}$ cells) and the 24th hour ( $8.8 \pm 4.1$ vs. $32.0 \pm 6.2 \mathrm{ng} / 10^{6}$ cells). These data suggested that anti-IgE stimulation in- duced a rapid increase in the release of MCP-1 into the medium.

On the other hand, the gradual decline in MCP-1 levels starting at the 6th hour after anti-IgE stimulation raised the possibility that MCP-1 expression might be downregulated in the later time period of anti-IgE stimulation. To assess such a possibility, we performed quantitative PCR to measure mRNA expression of MCP-1 in control and anti-IgE stimulated HCMC (Fig. 2c). MCP-1 mRNA levels were 1.8-fold higher in anti-IgE stimulated cells than in control cells after $30 \mathrm{~min}(p<0.0001)$, suggesting that MCP-1 gene transcription increased significantly in response to anti-IgE stimulation as early as $30 \mathrm{~min}$. However, after $24 \mathrm{~h}$, there was no significant difference in mRNA levels of MCP-1 between stimulated and control cells $(p=0.5181)$, suggesting that the gradual decline in MCP-1 release after a prolonged period could not be attributed to a decrease in de novo MCP-1 synthesis. 
Fig. 2. Time course of MCP-1 release from human cultured mast cells. a Under basal conditions. b Following activation by 0.25 $\mu \mathrm{g} / \mathrm{mL}$ anti-IgE. All values are means \pm SEM $(n=3) .{ }^{* *} p<0.01$ and ${ }^{* * *} p<0.001$ by one-way ANOVA with Dunn's multiple comparisons test when compared with the value at $1 \mathrm{~h}$. c Expression of MCP-1 mRNA in human cultured mast cells in basal conditions and after $30 \mathrm{~min}$ and $24 \mathrm{~h}$ of stimulation with $0.25 \mu \mathrm{g} / \mathrm{mL}$ anti-IgE. All values are means $\pm \operatorname{SEM}(n=3) .{ }^{* * * *} p<0.0001$ by unpaired $t$ test when compared with the corresponding basal level.
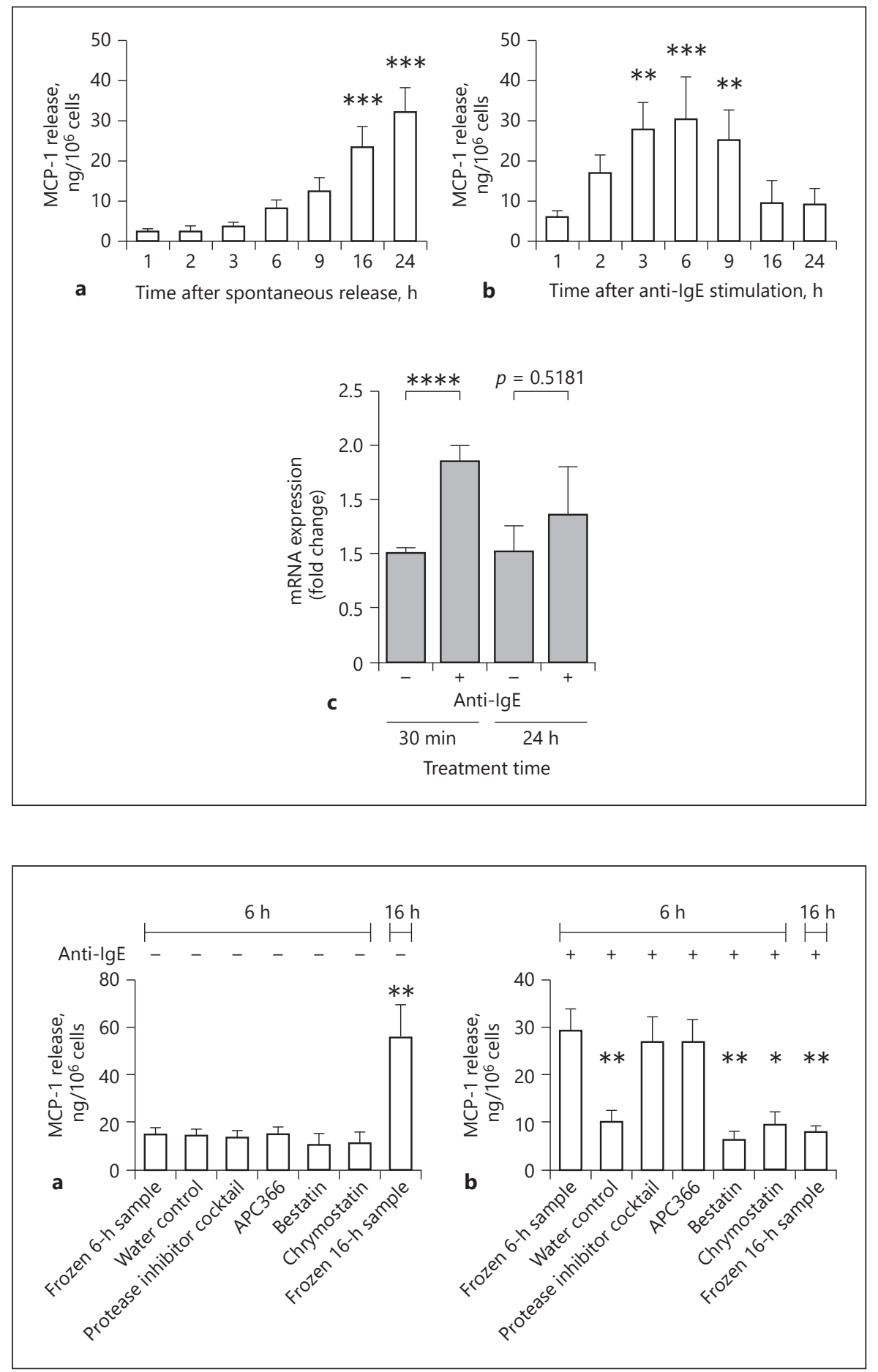

Fig. 3. Effects of different protease inhibitors on levels of MCP-1 release from human cultured mast cells. a Under basal conditions. b In response to $0.25 \mu \mathrm{g} / \mathrm{mL}$ anti-IgE stimulation. All values are means $\pm \operatorname{SEM}(n=5-9) .{ }^{*} p<0.05$ and ${ }^{* *} p<0.01$ by unpaired $t$ test when compared with the control frozen 6-h sample.

\section{Degradation of MCP-1 by Tryptase Co-Released from} Anti-IgE-Activated HCMC

To assess whether MCP-1 released from HCMC was degraded by preformed granular proteases co-released after activation of the high-affinity IgE receptors, differ- ent protease inhibitors were tested for their abilities to inhibit the decrease in MCP-1 levels. IgE-sensitized HCMC with or without anti-IgE activation were incubated at $37^{\circ} \mathrm{C}$ for $6 \mathrm{~h}$. Cell-free supernatants were then collected and subsequently treated with water (vehicle) 
or different protease inhibitors for an additional $16 \mathrm{~h}$ at $37^{\circ} \mathrm{C}$. MCP-1 levels in the treated supernatants were then determined. As a control, MCP-1 protein released by unstimulated cells into the medium was harvested at the 6th hour and frozen immediately for subsequent analysis. As shown in Figure 3a, for all MCP-1 samples derived from nonactivated HCMC, no MCP-1 degradation was observed among all of the 6th hour samples, regardless of their subsequent treatments (range: $10.5 \pm$ 4.8 to $14.8 \pm 3.3 \mathrm{ng} / 10^{6}$ cells). In comparison, samples harvested from unstimulated cells at the 16th hour showed significantly higher MCP-1 levels than samples at the 6th hour $\left(55.8 \pm 13.4\right.$ vs. $14.7 \pm 3.1 \mathrm{ng} / 10^{6}$ cells, respectively). On the other hand, in the absence of any protease inhibitor treatment (i.e., water vehicle control), the MCP-1 levels in samples collected from anti-IgEactivated HCMC decreased significantly after the 16th hour with incubation at $37^{\circ} \mathrm{C}$ when compared with the 6th-hour sample $\left(10.1 \pm 2.3\right.$ vs. $28.9 \pm 5.1 \mathrm{ng} / 10^{6}$ cells, respectively; Fig 3b). However, MCP-1 levels were not affected in those anti-IgE-activated HCMC samples that were treated with either the protease inhibitor cocktail $\left(27.2 \pm 4.9 \mathrm{ng} / 10^{6}\right.$ cells $)$ or $500 \mu \mathrm{g} / \mathrm{mL}$ APC 366 , a tryptase-specific inhibitor $\left(26.5 \pm 5.1 \mathrm{ng} / 10^{6}\right.$ cells $)$. In contrast, MCP-1 degradation was not inhibited by $500 \mu \mathrm{M}$ bestatin, a metalloprotease inhibitor $\left(6.2 \pm 1.9 \mathrm{ng} / 10^{6}\right.$ cells), or $100 \mu \mathrm{g} / \mathrm{mL}$ chymostatin, a chymase inhibitor $\left(9.7 \pm 2.5 \mathrm{ng} / 10^{6}\right.$ cells $)$.

\section{Discussion}

We recently developed a novel protocol for generating large homogenous populations of mature and functional HCMC from buffy coats that can respond to different mast cell stimuli, including substance $\mathrm{P}$, by releasing different preformed and newly synthesized mediators and cytokines that are characteristic of connective tissue-type mast cells $\left(\mathrm{MC}_{\mathrm{TC}}\right)$ [6]. In this study, we showed that nonactivated HCMC spontaneously released the chemokine MCP-1 in basal conditions and that the released MCP-1 levels increased in a time-dependent manner. On the other hand, an enhanced release of MCP-1 from HCMC was induced by FceRI cross-linking but the elevated MCP-1 levels gradually decreased over time to levels that were lower than those observed with basal spontaneous release (Fig. 1, 2). The reduction of MCP-1 levels was also observed when these mast cells were activated with substance $\mathrm{P}$, which bypasses FceRI to induce degranulation, thus suggesting that the reduced MCP-1 levels are linked to the granular contents co-released at the time of mast cell activation. Similar findings on spontaneous and activated release of MCP-1 from human mast cells were reported in a recent study in which $\mathrm{HCMC}$ with the $\mathrm{MC}_{\mathrm{TC}}$ phenotype were generated using a culturing protocol that is entirely different from ours [9], suggesting that our observations are most unlikely an experimental artifact induced by specific culturing conditions employed in our culturing protocol. Moreover, gene expression studies (Fig. 2b) showed that $M C P-1$ mRNA levels were elevated shortly after FceRI cross-linking (30 min), while they returned to normal levels after a prolonged period of time (24 h).

MCP-1 is a potent monocyte attractant and has been reported to be involved in various diseases. Migration of monocytes from the blood stream across the vascular endothelium is required for routine immunological surveillance of tissues and in response to inflammation [10]. Mast cells are known to secrete the MCP-1 protein, but they are also recruited to the inflammatory sites by this chemokine. Thus, an investigation on the feedback mechanism for the regulation of MCP-1 levels may help us to gain some insights into the leucocyte-attracting property of tissue mast cells.

Using a panel of inhibitors of tryptase and chymase, we showed that the gradual decrease in MCP-1 levels was mediated by proteolytic degradation of the MCP-1 protein by tryptase that was co-released from the activated human mast cells. The decline in MCP-1 levels detected in the medium after IgE-dependent cell activation was completely prevented by pretreatment with protease inhibitor cocktail or the specific tryptase inhibitor APC366, but not by inhibitors of chymase and metalloprotease, suggesting the direct regulation of MCP-1 protein levels by tryptase co-released by HCMC upon IgE-dependent activation (Fig. 3). Therefore, the following scenario that describes the mechanisms of such actions can be proposed: HCMC slowly but spontaneously release MCP-1 protein which accumulates stably in the medium in a time-dependent manner. FceRI crosslinking of these cells with anti-IgE induces an additional increase in MCP-1 release. However, the time-dependent proteolytic activity of tryptase co-released during degranulation can gradually degrade $\mathrm{MCP}-1$ protein that has accumulated in the medium, thus causing the MCP-1 levels to drop $6 \mathrm{~h}$ after degranulation.

Several recent studies using different mouse models have suggested that serglycin proteoglycan and its associated proteases present in the granules of mast cells are 
involved in regulation of many inflammatory responses [3-5]. Depending on the experimental settings, the release of these proteases from mast cells upon degranulation can have either beneficial or detrimental effects on cell surroundings [11-19]. The mechanisms by which such proteases released by mast cells regulate inflammation involve either proteolytic activation or proteolytic degradation of cytokines in the extracellular environment. Several reports have shown that mast cell serine proteases can proteolytically activate cytokines and chemokines [20-24]. On the other hand, a recent report demonstrated that activated cultured mouse peritoneal mast cells can regulate levels of IL-3, IL-6, IL-13, IL-17A, and eotaxin by releasing serglycin-dependent serine proteases, which mediate the proteolytic degradation of these cytokines and chemokines [25]. Previous in vitro studies with purified human skin-derived mast cells have shown that chymase and cathepsin $G$ released upon FceRI cross-linking degrade cytokines, such as IL- 6 and IL-13, that are co-released from these activated mast cells [7]. In this study, we have further demonstrated that tryptase released from HCMC following FceRI cross-linking can degrade the MCP-1 co-released from the stimulated mast cells. Thus, our data are consistent with the view that human mast cells release proteases that can degrade cytokines that are co-released during cell activation. Taken together, the data obtained from studies of both mouse and human mast cells are consistent with a role of the serglycin:serine protease axis in the downregulation of levels of inflammatory cytokines [3-5].

\section{Acknowledgment}

This work was supported by University-Industry Collaboration Programme UIM/186 of the Innovation and Technology Fund of Hong Kong, China (H.Y.A.L). S.-Y.T. was supported in part by National Institutes of Health (NIH) grant AI-23990 and by the Department of Pathology of the Stanford University School of Medicine.

\section{Statement of Ethics}

The use of human buffy coat preparations for the culturing of human mast cells was approved by The Joint Chinese University of Hong Kong - New Territories East Cluster Clinical Research Ethics Committee.

\section{Disclosure Statement}

Some of the data described in this report were included in a patent application filed with the US Patent Office.

\section{References}

1 Galli SJ, Tsai M: IgE and mast cells in allergic disease. Nat Med 2012;18:693-704.

2 Voehringer D: Protective and pathological roles of mast cells and basophils. Nat Rev Immunol 2013;13:362-375.

3 Caughey GH: Mast cell proteases as protective and inflammatory mediators. Adv Exp Med Biol 2011;716:212-234.

4 Pejler G, Rönnberg E, Waern I, Wernersson S: Mast cell proteases: multifaceted regulators of inflammatory disease. Blood 2010;115: 4981-4990.

5 Wernersson S, Pejler G: Mast cell secretory granules: armed for battle. Nat Rev Immunol 2014; 14:478-494

6 Tam IY, Ng CW, Tam SY, Lau HY: Novel sixweek protocol for generating functional human connective tissue-type (MCTC) mast cells from buffy coats. Inflamm Res 2017;66: 25-37.

7 Zhao W, Oskeritzian CA, Pozez AL, Schwartz LB: Cytokine production by skin-derived mast cells: endogenous proteases are responsible for degradation of cytokines. J Immunol 2005; 175:2635-2642.
8 Deshmane SL, Kremlev S, Amini S, Sawaya BE: Monocyte chemoattractant protein-1 (MCP-1): an overview. J Interferon Cytokine Res 2009;29:313-326.

9 Gaudenzio N, Sibilano R, Marichal T, et al: Different activation signals induce distinct mast cell degranulation strategies. J Clin Invest 2016;126:3981-3998.

10 Yadav A, Saini V, Arora S: MCP-1: chemoattractant with a role beyond immunity: a review. Clin Chim Acta 2010;411:1570-1579.

11 Beghdadi W, Madjene LC, Claver J, et al: Mast cell chymase protects against renal fibrosis in murine unilateral ureteral obstruction. Kidney Int 2013;84:317-326.

12 Lin L, Bankaitis E, Heimbach L, et al: Dual targets for mouse mast cell protease- 4 in mediating tissue damage in experimental bullous pemphigoid. J Biol Chem 2011;286:3735837367.
13 Nelissen S, Vangansewinkel T, Geurts N, et al: Mast cells protect from post-traumatic spinal cord damage in mice by degrading inflammation-associated cytokines via mouse mast cell protease 4. Neurobiol Dis 2014;62:260-272.

14 Reber LL, Daubeuf F, Pejler G, et al: Mast cells contribute to bleomycin-induced lung inflammation and injury in mice through a chymase/mast cell protease 4 -dependent mechanism. J Immunol 2014;192:1847-1854.

15 Sun J, Zhang J, Lindholt JS, et al: Critical role of mast cell chymase in mouse abdominal aortic aneurysm formation. Circulation 2009; 120:973-982.

16 Waern I, Jonasson S, Hjoberg J, et al: Mouse mast cell protease 4 is the major chymase in murine airways and has a protective role in allergic airway inflammation. J Immunol 2009;183:6369-6376.

17 Waern I, Lundequist A, Pejler G, Wernersson S: Mast cell chymase modulates IL-33 levels and controls allergic sensitization in dustmite induced airway inflammation. Mucosal Immunol 2013;6:911-920. 
18 Younan G, Suber F, Xing W, et al: The inflammatory response after an epidermal burn depends on the activities of mouse mast cell proteases 4 and 5. J Immunol 2010;185:76817690.

19 Piliponsky AM, Chen CC, Rios EJ, et al: The chymase mouse mast cell protease 4 degrades TNF, limits inflammation, and promotes survival in a model of sepsis. Am J Pathol 2012; 181:875-886

20 Berahovich RD, Miao Z, Wang Y, et al: Proteolytic activation of alternative CCR1 ligands in inflammation. J Immunol 2005;174:73417351.
21 Lefrançais E, Duval A, Mirey E, et al: Central domain of IL-33 is cleaved by mast cell proteases for potent activation of group-2 innate lymphoid cells. Proc Natl Acad Sci USA 2014; 111:15502-15507.

22 Lindstedt KA, Wang Y, Shiota N, et al: Activation of paracrine TGF-betal signaling upon stimulation and degranulation of rat serosal mast cells: a novel function for chymase. FASEB J 2001;15:1377-1388.

23 Mizutani H, Schechter N, Lazarus G, et al: Rapid and specific conversion of precursor interleukin 1 beta (IL-1 beta) to an active IL-1 species by human mast cell chymase. J Exp Med 1991;174:821-825.
24 Schiemann F, Grimm TA, Hoch J, et al: Mast cells and neutrophils proteolytically activate chemokine precursor CTAP-III and are subject to counterregulation by PF-4 through inhibition of chymase and cathepsin G. Blood 2006;107:2234-2242

25 Waern I, Karlsson I, Pejler G, Wernersson S: IL-6 and IL-17A degradation by mast cells is mediated by a serglycin:serine protease axis. Immun Inflamm Dis 2015;4:70-79. 